\title{
Phytochemical and antibacterial properties of root extracts from Portulaca oleracea Linn. (Purslane) utilised in the management of diseases in Nigeria
}

\begin{tabular}{|c|c|}
\hline \multicolumn{2}{|c|}{$\begin{array}{l}\text { Authors: } \\
\text { Emmanuel O. Ojah }{ }^{1} \text { (1) } \\
\text { Emmanuel O. Oladele }^{2} \\
\text { Philip Chukwuemeka }^{3}\end{array}$} \\
\hline \multicolumn{2}{|c|}{ 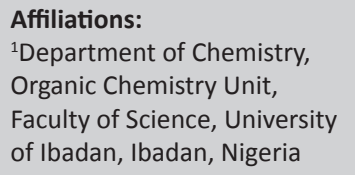 } \\
\hline \multicolumn{2}{|c|}{$\begin{array}{l}{ }^{2} \text { Department of Biochemistry, } \\
\text { College of Basic Medical } \\
\text { Sciences, University of } \\
\text { Ibadan, Ibadan, Nigeria }\end{array}$} \\
\hline \multicolumn{2}{|c|}{$\begin{array}{l}{ }^{3} \text { Department of } \\
\text { Pharmaceutical Chemis } \\
\text { Faculty of Pharmacy, } \\
\text { University of Ibadan, } \\
\text { Ibadan, Nigeria }\end{array}$} \\
\hline \multicolumn{2}{|c|}{$\begin{array}{l}\text { Corresponding author: } \\
\text { Emmanuel Ojah, } \\
\text { eojah7403@stu.ui.edu.ng }\end{array}$} \\
\hline \multicolumn{2}{|c|}{$\begin{array}{l}\text { Dates: } \\
\text { Received: } 24 \text { Aug. } 2020 \\
\text { Accepted: } 01 \text { Dec. } 2020 \\
\text { Published: } 26 \text { Jan. } 2021\end{array}$} \\
\hline \multicolumn{2}{|c|}{$\begin{array}{l}\text { How to cite this article: } \\
\text { Ojah, E.O., Oladele, E.O. } \\
\text { \& Chukwuemeka, P., } \\
\text { 2021, 'Phytochemical and } \\
\text { antibacterial properties of } \\
\text { root extracts from Portulaca } \\
\text { oleracea Linn. (Purslane) } \\
\text { utilised in the management of } \\
\text { diseases in Nigeria', Journal of } \\
\text { Medicinal Plants for Economic } \\
\text { Development 5(1), a103. } \\
\text { https://doi.org/10.4102/ } \\
\text { jomped.v5i1.103 }\end{array}$} \\
\hline \multicolumn{2}{|l|}{ Read onlin } \\
\hline 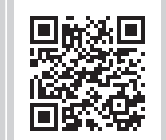 & $\begin{array}{l}\text { Scan this QR } \\
\text { code with your } \\
\text { smart phone or } \\
\text { mobile device } \\
\text { to read online. }\end{array}$ \\
\hline
\end{tabular}

\section{Authors:}

Emmanuel O. Oladele ${ }^{2}$

Philip Chukwuemeka ${ }^{3}$

Affiliations:

Faculty of Science, University

${ }^{2}$ Department of Biochemistry,

College of Basic Medical

Sciences, University of

${ }^{3}$ Department of

Pharmaceutical Chemistry,

Faculty of Pharmacy,

University of Ibadan,

Corresponding author:

Emmanuel Ojah,

Dates:

How to cite this article: Ojah, E.O., Oladele, E.O.

2021, 'Phytochemical and antibacterial properties of root extracts from Portulaca oleracea Linn. (Purslane) Medicinal Plants for Economic Development 5(1), a103. https://doi.org/10.4102/ jomped.v5i1.103
Background: Bacteria as etiological agents have been reported to cause many diseases and have increased the rate of mortality globally. Their resistance to conventional medicine has made medicinal plants a credible alternative in the management of diseases caused by bacterial infection. In the recent times many research efforts have been directed towards the exploration of phytoconstituents with antibacterial potentials. Medicinal plants are widely used as antibacterial agents because of their high therapeutic performance, low toxicity, and affordability.

Aim: This work was designed to identify secondary metabolites present in root extracts of ethno-medicinally utilised Portulaca oleracea L. and evaluate their antibacterial activities.

Setting: The roots of P. oleracea L. were obtained from the Forest Research Institute of Nigeria (FRIN), Ibadan, Nigeria and authenticated in the Forest Research Herbarium, where voucher samples were deposited with specimen voucher number FIH-112030.

Methods: Phytochemical screening was carried out using standard qualitative tests and the antibacterial activity of extracts was evaluated using agar well diffusion method whilst the minimum inhibitory concentration (MIC) was evaluated by micro-dilution method. The screening was assessed against Bacillus subtilis, Candida albicans, Enterobacter cloacae, Escherichia coli, Klebsiella pneumoniae, Micrococcus luteus, Pseudomonas aeruginosa, Salmonella typhi, Shigella dysenteriae, Staphylococcus aureus and Streptococcus agalactiae, which are responsible for the transmission of common diseases in Nigeria. Statistical analysis was performed by one-way analysis of variance (ANOVA) with GraphPad Prism 8.0 and results were expressed as mean \pm s.d. Duncan's New Multiple range test were applied at 0.05 level of significance $(p<0.05)$.

Results: Phytochemical screening of P. oleracea L. showed the presence of carbohydrates, steroids, triterpenes, cardiac glycosides, and saponins. All extracts showed a high level of minimum inhibition concentration against the pathogens except K. pneumoniae, M. luteus and $P$. aeruginosa. Generally the antibacterial activity of extracts increased with decrease in polarity as compared with ciprofloxacin. The mean ( \pm s.d.) values were significantly different by Duncan's multiple range tests with $p<0.05$.

Conclusion: Portulaca oleracea L. has been identified for the first time as a good antibacterial agent, which corroborates the ethno-medicinal uses of the plant.

Keywords: Portulaca oleracea; Portulacaceae; maceration; phytochemicals; antibacterials; ciprofloxacin.

\section{Introduction}

The use of plants as medicine predates written human history. It is estimated that about $80 \%$ of people living in underdeveloped and developing countries rely on plant as a source of primary healthcare (Ajala, Olusola \& Odeku 2020; Ojah, Moronkola \& Osamudiamen 2020; Ojah \& Kachi 2020; Rafiu, Sonibare \& Adesanya 2019). Approximately half of medicines in the world are derived from natural products and more than a quarter of the prescriptions dispensed annually in the United States were initially derived from plants. It was also reported that $80 \%$ of the world's population directly or indirectly utilise herbal medicine for the treatment or prevention of diseases (Newman, Cragg \& Snader 2000). A wide variety of phyto-constituents perform essential biological, pharmacological, and physiological functions. Research has shown that at least 12000

Copyright: (C) 2021. The Authors. Licensee: AOSIS. This work is licensed under the Creative Commons Attribution License. 
bioactive compounds have been isolated in recent times (Dosumu et al. 2019; Motaleb 2010). Phytochemicals mediate their effect on the human body through processes similar to those understood in conventional drugs, thus plant medicines are not only as effective as orthodox medicines but also pose side effects. Plants parts such as roots, leaves, stem bark and seeds possess some active components that are of therapeutic value and hence useful in the treatment of diseases such as cancer, coronary heart disease, diabetes and infectious disease. Many of the herbal medicines that proved to be effective have been incorporated into modern medicine (Motaleb 2010).

Medicinal plants provide a wealth of antimicrobial agents, which can be used as an alternate source of antibiotics (Malik et al. 2011; Walter et al. 2011; Prasannabalaji et al. 2012). Secondary metabolites in plants act as antibacterial agent that is utilised as therapy or prophylactics against several infections caused by bacteria (Nasrullah et al. 2012). In the last few decades, most pathogenic bacteria developed resistance to many antibiotics and this is a major threat to human health. Medicinal plants are sources of diverse molecules, many of which display antimicrobial properties, which protect human body from pathogenic infections. Thus, it is important to characterise different medicinal plants for their antibacterial potential (Bajpai et al. 2005; Wojdylo, Oszmianski \& Czemerys 2007). A large number of antibacterial agents derived from traditional medicinal plants are available for treating various diseases caused by microorganisms (Jain 1994). Plants generally, produce phytochemicals that have antibacterial activity. In the last few years, many bacterial organisms have continued to show increasing multidrug resistance to several antibacterial agents (Njenga \& Mugo 2020). Although hundreds of plant species have been tested for antibacterial properties, the vast majority have not been adequately evaluated (Balandrin et al. 1985; Muthusamy et al. 2013).

Portulaca oleracea L. commonly known as purslane is a warm-climate herbaceous succulent annual plant with a cosmopolitan distribution belonging to Portulacaceae family. It is commonly known as purslane (United States and Australia), rigla (Egypt), pigweed (England), pourpier (France) and Ma-Chi-Xian (China) (Elkhayat, Ibrahim \& Aziz 2008). It is distributed widely in the tropical and subtropical areas of the world, including many parts of the United States and is eaten extensively as a potherb and is added to soups and salads around the Mediterranean and tropical Asian countries (Palaniswamy, Bible \& McAvoy 2002). This plant might have originated in Asia and is now ubiquitous in Africa and the Mediterranean region (Masoodi et al. 2011). Portulaca oleracea also provides a source of nutritional benefits owing to its rich omega-3 fatty acids and antioxidant properties (Palaniswamy, McAvoy \& Bible 2001). The plant contains many biologically active compounds, which are responsible for the wide application of the plant in medicine. The plant has been reported as a rich source of phytoconstituents, such as oxalic acids, alkaloids, omega-3 fatty acids, coumarins, flavonoids, cardiac glycosides and anthraquinone glycosides (Ezekwe et al. 1999). Crude extracts of $P$. oleracea have been found to possess potent wound-healing properties (Rashed, Afifi \& Disi 2003). The plant possesses culinary property utilised in the preparation of salads, soups and pickles. It has been used in folk medicine in many countries as febrifuge, antiseptic and vermifuge (Lee et al. 2012.). It exhibits a wide range of pharmacological effects such as antiulcerogenic (Karimi, Hosseinzadeh \& Ettehad 2004), anti-inflammatory (Chan, Islam \& Kamil 2000), antioxidant (Rashed et al. 2003), and wound-healing (Xu, Yu \& Chen 2006) properties. It is listed by the World Health Organization as one of the most used medicinal plants, and it has been given the term 'Global Panacea' (Chen, Wang \& Wang 2009). The Chinese folklore described it as 'vegetable for long life' and it has been used for thousands of years in traditional Chinese medicine (Jin et al. 2013; Li, Wu \& Chen 2013). It is cold in nature and sour in taste and is used to cool the blood, stanch bleeding, clear heat and resolve toxins. The dried aerial part of this plant is used for the treatment of fever, dysentery, diarrhoea, carbuncle, eczema, and hematochezia ( $\mathrm{Li}$ et al. 2013; Zhao et al. 2014).

Although orthodox medicine has been accepted by some populations of the world, yet greater percentage still rely on natural remedies to diseases caused by bacteria. Hence, this study was designed to evaluate the antibacterial activity of phytoconstituents present in root extracts of Nigerian P. oleracea. L.

\section{Materials and methods Plant material}

The roots of $P$. oleracea L. were collected from the Forest Research Institute of Nigeria (FRIN), Ibadan, Nigeria and authenticated in the Forest Research Herbarium, Ibadan, Nigeria where voucher samples were deposited with specimen voucher number FIH-112030.

\section{Plant preparation and extraction}

The roots of the plant were air-dried at a temperature below $40{ }^{\circ} \mathrm{C}$ and pulverised using a laboratory milling machine into fine powder after which a total of $500 \mathrm{~g}$ each of the ground powder were extracted successively in n-hexane, ethyl acetate, chloroform, and methanol by maceration using $5 \mathrm{~L}$ each of respective solvents (volume per volume $[\mathrm{v} / \mathrm{v}])$. The extract was concentrated using a rotary evaporator (Buchi model R210, Switzerland) and dried in a vacuum desiccator. The dried extract was reduced to powder using a laboratory mill and then sieved with a $250-\mu \mathrm{m}$ mesh sieve.

\section{Phytochemical screening}

Phytochemical examinations were carried out for all the extracts using standard qualitative tests. 


\section{Test for steroid}

\section{Liebermann-Burchard test}

About $0.2 \mathrm{~g}$ of extract was dissolved in chloroform and few drops of acetic anhydride and concentrated sulphuric acid were added to the chloroform solution. Violet blue and finally green colour was formed indicating the presence of steroids (Harborne 1998; Talukdar et al. 2010).

\section{Salkowski test}

About $0.2 \mathrm{~g}$ of extract was dissolved in chloroform and a few drops of concentrated sulphuric acid were added to the solution. A reddish colour in the upper chloroform layer was observed indicating the presence of steroids (Kumar et al. 2007).

\section{Test for alkaloids}

\section{Dragendroff's test}

About $0.2 \mathrm{~g}$ of the extract was warmed with $2 \% \mathrm{H}_{2} \mathrm{SO}_{4}$ for $2 \mathrm{~min}$. It was filtered and few drops of Dragendroff's reagent were added. Orange red precipitate indicates the presence of alkaloids (Egwaikhide \& Gimba 2007).

\section{Mayer's test}

To a few milliliters of filtrate, a few drops of Mayer's reagent were added by the side of the tube. A creamy white precipitate confirms the presence of alkaloids (Narasimhan et al. 2012).

\section{Test for flavonoid}

\section{Shinoda test}

To $3 \mathrm{~mL}$ of $5 \mathrm{mg}$ of methanolic extract, a piece of magnesium ribbon was added and $1 \mathrm{~mL}$ of concentrated hydrochloric acid. Pink-red or red colouration of the solution indicates the presence of flavonoids (Ajala et al. 2020).

\section{$\mathrm{NaOH}$ test}

About $0.5 \mathrm{~g}$ of extract was treated with $10 \% \mathrm{NaOH}$ solution; formation of intense yellow colour indicates the presence of flavonoid (Sawant \& Godghate et al. 2013).

\section{Test for phenolic compounds}

The extract $(500 \mathrm{mg}$ ) was dissolved in $5 \mathrm{~mL}$ of distilled water. To this, a few drops of neutral 5\% ferric chloride solution were added. A dark green colour indicated the presence of phenolic compounds (Mir, Sawheny \& Jassal 2013).

\section{Test for glycoside}

\section{Kellar-Kiliani test}

A total of $2 \mathrm{~mL}$ of filtrate was added to $1 \mathrm{~mL}$ of glacial acetic acid, $1 \mathrm{~mL}$ ferric chloride and $1 \mathrm{~mL}$ concentrated sulphuric acid. Green-blue colouration of solution confirms the presence of glycosides (Chhetri et al. 2008; Parekh \& Chanda 2007).

\section{Test for tannins}

To $0.5 \mathrm{~mL}$ of extract solution $1 \mathrm{~mL}$ of water and $1-2$ drops of ferric chloride solution were added. Blue colour was observed for gallic tannins and green-black for catecholic tannins (Talukdar et al. 2010).

\section{Test for saponins}

\section{Frothing test or foam test}

A total of $0.5 \mathrm{~mL}$ of filtrate was added to $5 \mathrm{~mL}$ of distilled water and shaken properly. Persistence of frothing on the solution confirmed the presence of saponins (Victor \& Chidi 2009).

\section{Test for carbohydrates \\ Molisch's test}

Few drops of Molisch's reagent were added to each of the portion dissolved in distilled water, this was then followed by addition of $1 \mathrm{~mL}$ of concentrated $\mathrm{H}_{2} \mathrm{SO}_{4}$ by the side of the test tube. The mixture was then allowed to stand for $2 \mathrm{~min}$ and then diluted with $5 \mathrm{~mL}$ of distilled water. Formation of a red or dull violet colour at the interphase of the two layers was a positive test (Sofowora 1993).

\section{Fehling's test}

About $0.5 \mathrm{~g}$ each of the extract was dissolved in distilled water and filtered. The filtrate was heated with $5 \mathrm{~mL}$ of equal volumes of Fehling's solution A and B. Formation of a red precipitate of cuprous oxide was an indication of the presence of reducing sugars (Sofowora 1993).

\section{Test organisms}

The antibacterial activities of the extract were determined using the agar well diffusion method of Balouiri, Sadiki and Ibnsouda (2016). The bacteria isolates used include Staphylococcus aureus (UCH 2473), Bacillus subtilis (UCH 7423), Salmonella typhi (UCH 4801), Shigella dysenteriae, Escherichia coli (UCH 0026), Enterobacter cloacae (UCH 1002), Streptococcus agalactiae (UCH 0102), Micrococcus luteus (UCH 1862), Pseudomonas aeruginosa (UCH 1102) and Klebsiella pneumonia (UCH 2894), which are responsible for the transmission of common diseases in Nigeria. They were obtained from the Department of Microbiology, University College Hospital, Ibadan, Nigeria. All the isolates were checked for purity and maintained in nutrient agar.

\section{Antibacterial screening procedure}

The antibacterial activities of the extracts were tested against the selected strains using agar well diffusion method as described by Mbata, Debiao and Saikia (2008). An amount of $20 \mathrm{~mL}$ of sterilised nutrient agar medium was poured into each sterile Petri dish and allowed to solidify. The test bacteria cultures were standardised to $0.5 \%$ McFarland standard (NCCLS 1993) and evenly spread over the appropriate media with the aid of a swab stick. 
Then wells of $6 \mathrm{~mm}$ were made in the medium using a sterile cork borer (Bhargav et al. 2016). Concentrations of sample solutions were prepared followed by appropriate dilutions to the required concentration $(10 \mathrm{mg} / \mathrm{mL})$. These concentrations (at $0.1 \mathrm{~mL}$ ) were transferred into separate wells, followed by the incubation of the plates at $35{ }^{\circ} \mathrm{C}$ for $24 \mathrm{~h}$. After the incubation period, the zones of growth inhibition (ZI) were observed and measured using transparent ruler (Mbata, Debiao, \& Saikia, 2008). Each test was repeated three times to ensure reproducibility. The mean of the triplicate tests \pm their standard error of mean (SEM) was calculated and recorded as the diameter of zone of inhibition. Standard sensitivity discs of selected antibiotics ciprofloxacin, was used as positive control. Active plant extracts showing visible zones of inhibition were further tested at lower concentrations to determine their minimum inhibitory concentration (MIC), using the broth microdilution method in 96-well microtitre plate (Essawi \& Srour 2000; Janet \& John 2007). The minimum bactericidal concentration (MBC) was determined by subculture of the preparations that have shown no evidence of growth in the MIC determination assay. These subcultures were made in nutrient agar plates (Grierson \& Afolayan 1999; Muthusamy et al. 2013).

\section{Statistical analysis}

The experiments were conducted three times and all determinations were performed in triplicates $(n=3)$ and results were expressed as mean \pm s.d. Statistical analysis was performed by one-way analysis of variance (ANOVA) with GraphPad Prism statistical software package, version 8 . Duncan's new multiple range test were applied to the result at 0.05 level of significance $(p<0.05)$.

\section{Ethical consideration}

This article followed all ethical standards for research without direct contact with human or animal subjects.

\section{Results and discussion}

The present study identified secondary metabolites present in root hexane, ethyl acetate, chloroform and methanol extracts of $P$. oleracea using standard methods (Trease \&
Evans 2002). Phytochemical screening on root extracts showed the presence of carbohydrates, steroids, triterpenes, cardiac glycosides and saponins (Table 1). The presence of these useful phytochemicals could be responsible for the observed antibacterial activities and can be seen as a potential source of antibiotic drugs. In general, the accumulation and concentration of secondary metabolites are responsible for the antibacterial activity of a plant (Tim-Cushnie \& Andrew 2005). Flavonoids possess antibacterial, antifungal and antiviral activity (Cowan 1999). Tannins are known for their astringent property and antimicrobial activity. Alkaloids are good antibacterial drugs whilst saponins possess antibacterial and anticandidal activity as reported in literature (Maatalah et al. 2012; Ramanathan et al. 2013; Tim-Cushnie, Benjamart \& Andrew 2014).

Antibacterial screening on root hexane, ethyl acetate, chloroform and methanol extracts of $P$. oleracea exhibited good activity against the tested organisms from the zones of inhibition obtained (Table 2). The inhibitory effect was compared with standard antibiotic drugs ciprofloxacin at $10 \mathrm{mg} / \mathrm{mL}$. The significant activity of methanol extract was maximum against E. cloacae $(24 \pm 0.3 \mathrm{~mm})$ followed by B. subtilis $(23 \pm 0.6 \mathrm{~mm})$. Staphylococcus aureus, E. coli had $22 \pm 0.4 \mathrm{~mm}$ as zone of inhibition. Streptococcus agalactiae had zone of inhibition of $21 \pm 0.4 \mathrm{~mm}$ when exposed to the extracts. Salmonella typhi and S. dysenteriae had the least zones of inhibition $(20 \pm 0.7 \mathrm{~mm})$. Enterobacter cloacae had the highest zone of inhibition in the ethyl acetate extract $(31 \pm 0.4 \mathrm{~mm})$ whilst the least activity was observed in $S$. dysenteriae $(22 \pm 0.4 \mathrm{~mm})$. Enterobacter cloacae had the highest zone of inhibition in the chloroform extract (31 \pm $0.4 \mathrm{~mm}$ ) whilst the least activity was observed in $S$. dysenteriae $(22 \pm 0.4 \mathrm{~mm})$. Streptococcus agalactiae had the highest inhibition in the hexane extract $(28 \pm 0.5 \mathrm{~mm})$ whilst $S$. dysenteriae had the least activity $(23 \pm 0.2 \mathrm{~mm})$. Klebsiella pneumoniae, M. luteus and P. aeruginosa had zero activity in all extracts tested. Ciprofloxacin and fluconazole, standard antibiotic drugs had the highest zones of inhibition ( $\mathrm{mm}$ ) against all organisms tested; [(S. aureus, 35 $\pm 0.2 \mathrm{~mm})$, (B. subtilis, $37 \pm 0.2 \mathrm{~mm}$ ), (K. pneumoniae, $30 \pm$ $0.2 \mathrm{~mm})$, (S. agalactiae, $32 \pm 0.3 \mathrm{~mm})$, (S. typhi, $41 \pm 0.2 \mathrm{~mm})$, (S. dysenteriae, $40 \pm 0.5 \mathrm{~mm}),($ E. coli, $39 \pm 0.4 \mathrm{~mm})$ and $(E$. cloacae, $35 \pm 0.2 \mathrm{~mm})$ ].

TABLE 1: Phytochemical constituents of the roots of Portulaca oleracea.

\begin{tabular}{|c|c|c|c|c|c|}
\hline Phytochemical & Test & Hexane & Ethyl acetate & Chloroform & Methanol \\
\hline \multirow[t]{2}{*}{ Alkaloids } & Dragendorff & - & - & - & - \\
\hline & Mayer & - & - & - & - \\
\hline \multirow[t]{2}{*}{ Carbohydrates } & Molisch & + & + & + & + \\
\hline & Fehling & + & + & + & + \\
\hline Anthraquinones & Bontrager & - & - & - & - \\
\hline Steroids & Liebermann-Burchard & + & + & + & + \\
\hline Triterpenes & Liebermann-Burchard & + & + & + & + \\
\hline Cardiac Glycosides & Killer-Killiani & + & + & + & + \\
\hline Saponins & Frothing & + & + & + & + \\
\hline Tannins & Ferric chloride & - & - & - & - \\
\hline \multirow[t]{2}{*}{ Flavonoids } & $\mathrm{NaOH}$ & - & - & - & - \\
\hline & Shinoda & - & - & - & - \\
\hline
\end{tabular}

+, detected; -, not detected. 
The MIC and MBC of extracts were determined in $\mathrm{mg} / \mathrm{mL}$ as presented in Tables 3 and 4, respectively. The MIC $(\mathrm{mg} / \mathrm{mL})$ revealed that the standard antibacterial drug ciprofloxacin had the highest activity with MIC values; [(S. aureus, $0.100 \pm 0.1)$, (B. subtilis, $0.080 \pm 0.2)$, (K. pneumoniae, $0.140 \pm 0.1)$, (S. agalactiae, $0.120 \pm 0.3)$, (S. typhi, $0.050 \pm 0.1)$, (S. dysenteriae, $0.052 \pm 0.2)$, (E. coli, $0.054 \pm 0.1)$, and (E. cloacae, $0.065 \pm 0.2$ )]. Also, $\mathrm{MBC}$ in $\mathrm{mg} / \mathrm{mL}$ revealed that the standard antibiotic drug ciprofloxacin had the highest activity with MBC values; [(S. aureus, $0.050 \pm 0.3)$, (B. subtilis, $0.050 \pm 0.2)$, (K. Pneumoniae, $0.100 \pm 0.1)$, (S. agalactiae, $0.100 \pm 0.2)$, (S. typhi, $0.010 \pm 0.4)$, (S. dysenteriae, $0.010 \pm 0.2)$, (E. coli, $0.010 \pm 0.2)$, and (E. cloacae, $0.050 \pm 0.1)$ ] The MIC and MBC revealed that hexane and chloroform extracts from $P$. oleracea had the highest antibacterial activity compared with ethyl acetate and methanol fractions. Generally the antibacterial activity of extracts increased with decrease in polarity in the order hexane $<$ chloroform $<$ ethyl acetate $<$ methanol.

The mean ( \pm s.d.) values were significantly different by Duncan's multiple range tests with $p<0.05$. The extracts showed significant activities against E. cloacae, the bacteria responsible for bacteremia, lower urinary and respiratory tract infections. Extracts also showed substantial activities against E. coli, the bacteria responsible for diarrhoea and stomach pain. The sensitivity of $S$. typhi, S. aureus, B. subtilis, $S$. agalactiae to all the extracts implies that chemical

TABLE 2: Antibacterial activity $(\mathrm{mg} / \mathrm{mL})$ of root extracts of Portulaca oleracea based on zones of inhibition.

\begin{tabular}{|c|c|c|c|c|c|}
\hline \multirow[t]{2}{*}{ Test organisms } & \multicolumn{4}{|c|}{ Zone of inhibition $(\mathrm{mm})$} & \multirow{2}{*}{$\begin{array}{c}\text { Ciprofloxacin } \\
10 \mathrm{mg} / \mathrm{mL}\end{array}$} \\
\hline & Methanol & Ethyl acetate & Chloroform & Hexane extract & \\
\hline Staphylococcus aureus & $22 \pm 0.2$ & $25 \pm 0.4$ & $27 \pm 0.3$ & $25 \pm 0.2$ & $35 \pm 0.2$ \\
\hline Bacillus subtilis & $23 \pm 0.6$ & $29 \pm 0.5$ & $28 \pm 0.2$ & $27 \pm 0.7$ & $37 \pm 0.2$ \\
\hline Klebsiella Pneumoniae & 0 & 0 & 0 & 0 & $30 \pm 0.2$ \\
\hline Streptococcus agalactiae & $21 \pm 0.4$ & $30 \pm 0.6$ & $25 \pm 0.2$ & $28 \pm 0.5$ & $32 \pm 0.3$ \\
\hline Salmonella typhi & $20 \pm 0.8$ & $29 \pm 0.4$ & $28 \pm 0.2$ & $25 \pm 0.3$ & $41 \pm 0.2$ \\
\hline Shigella dysenteriae & $20 \pm 0.6$ & $22 \pm 0.4$ & $25 \pm 0.3$ & $23 \pm 0.2$ & $40 \pm 0.5$ \\
\hline Micrococcus luteus & 0 & 0 & 0 & 0 & NA \\
\hline Escherichia coli & $22 \pm 0.4$ & $30 \pm 0.5$ & $26 \pm 0.8$ & $28 \pm 0.2$ & $39 \pm 0.4$ \\
\hline Enterobacter cloacae & $24 \pm 0.3$ & $31 \pm 0.4$ & $27 \pm 0.5$ & $25 \pm 0.1$ & $35 \pm 0.2$ \\
\hline Pseudomonas aeruginosa & 0 & 0 & 0 & 0 & NA \\
\hline
\end{tabular}

Note: All the results are mean \pm standard deviation $(n=3)$. The mean $( \pm$ s.d.) values are significantly different by Duncan's multiple range test $(p<0.05)$.

NA, not applicable.

TABLE 3: Minimum inhibitory concentration in $\mathrm{mg} / \mathrm{mL}$ of root extracts from $P$. oleracea.

\begin{tabular}{|c|c|c|c|c|c|}
\hline \multirow[t]{2}{*}{ Test organisms } & \multicolumn{4}{|c|}{ Extracts $(\mathrm{mg} / \mathrm{mL})$} & \multirow[t]{2}{*}{ Ciprofloxacin } \\
\hline & Methanol & Ethyl acetate & Chloroform & $n$-Hexane & \\
\hline Staphylococcus aureus & $1.00 \pm 0.4^{*}$ & $0.250 \pm 0.6^{* *}$ & $0.250 \pm 0.3 * *$ & $0.250 \pm 0.5 * *$ & $0.100 \pm 0.1$ \\
\hline Bacillus subtilis & $1.00 \pm 0.2^{*}$ & $0.125 \pm 0.7 * * *$ & $0.125 \pm 0.4 * * *$ & $0.125 \pm 0.5^{* * *}$ & $0.080 \pm 0.2$ \\
\hline Klebsiella pneumoniae & - & - & - & - & $0.140 \pm 0.1$ \\
\hline Streptococcus agalactiae & $1.00 \pm 0.2^{*}$ & $0.125 \pm 0.3 * * *$ & $0.125 \pm 0.6^{* * *}$ & $0.125 \pm 0.4 * * *$ & $0.120 \pm 0.3$ \\
\hline Salmonella typhi & $1.00 \pm 0.3^{*}$ & $0.125 \pm 0.5 * * *$ & $0.250 \pm 0.6 * *$ & $0.250 \pm 0.4 * *$ & $0.050 \pm 0.1$ \\
\hline Shigella dysenteriae & $1.00 \pm 0.7^{*}$ & $0.125 \pm 0.5 * * *$ & $0.250 \pm 0.2 * *$ & $0.250 \pm 0.6 * *$ & $0.052 \pm 0.2$ \\
\hline Micrococcus luteus & - & - & - & - & - \\
\hline Escherichia coli & $1.00 \pm 0.3^{*}$ & $0.125 \pm 0.7 * * *$ & $0.125 \pm 0.5 * * *$ & $0.125 \pm 0.5^{* * *}$ & $0.054 \pm 0.1$ \\
\hline Enterobacter cloacae & $1.00 \pm 0.5^{*}$ & $0.125 \pm 0.3 * * *$ & $0.250 \pm 0.1^{* *}$ & $0.250 \pm 0.6 * *$ & $0.065 \pm 0.2$ \\
\hline Pseudomonas aeruginosa & - & - & - & - & - \\
\hline
\end{tabular}

All the results are mean \pm s.d. $(n=3)$. The mean ( \pm s.d.) values are significantly different by Duncan's multiple range test.

$*, p<0.01 ; * *, p<0.001 ; * * *, p<0.02$.

TABLE 4: Minimum bactericidal concentration in $\mathrm{mg} / \mathrm{mL}$ of root extracts from $P$. oleracea.

\begin{tabular}{|c|c|c|c|c|c|}
\hline \multirow[t]{2}{*}{ Test organisms } & \multicolumn{4}{|c|}{ Extracts $(\mathrm{mg} / \mathrm{mL})$} & \multirow[t]{2}{*}{ Ciprofloxacin } \\
\hline & Methanol & Ethyl acetate & Chloroform & $n$-Hexane & \\
\hline Staphylococcus aureus & $4.00 \pm 0.5^{*}$ & $0.500 \pm 0.4^{* * *}$ & $0.500 \pm 0.3^{* * *}$ & $0.500 \pm 0.6^{* * *}$ & $0.050 \pm 0.3$ \\
\hline Bacillus subtilis & $2.00 \pm 0.4^{* *}$ & $0.250 \pm 0.7 * * *$ & $0.500 \pm 0.8 * *$ & $0.500 \pm 0.7 * *$ & $0.050 \pm 0.2$ \\
\hline Klebsiella pneumoniae & - & - & - & - & - \\
\hline Streptococcus agalactiae & $4.00 \pm 0.2^{*}$ & $0.250 \pm 0.3^{* * *}$ & $0.250 \pm 0.4^{* * *}$ & $0.250 \pm 0.7^{* * *}$ & $0.100 \pm 0.2$ \\
\hline Salmonella typhi & $4.00 \pm 0.6^{*}$ & $0.250 \pm 0.5^{* * *}$ & $0.500 \pm 0.4 * *$ & $0.500 \pm 0.7 * *$ & $0.010 \pm 0.4$ \\
\hline Microcooccus luteus & - & - & - & - & - \\
\hline Escherichia coli & $4.00 \pm 0.5^{*}$ & $0.250 \pm 0.4 * * *$ & $0.250 \pm 0.3 * * *$ & $0.250 \pm 0.7 * * *$ & $0.010 \pm 0.2$ \\
\hline Enterobacter cloacae & $2.00 \pm 0.4 * *$ & $0.250 \pm 0.6^{* * *}$ & $0.500 \pm 0.7 * *$ & $0.500 \pm 0.3^{* *}$ & $0.050 \pm 0.1$ \\
\hline Pseudomonas Aeruginosa & - & - & - & - & - \\
\hline
\end{tabular}

All results are mean \pm s.d. $(n=3)$. The mean $( \pm$ s.d.) values are significantly different by Duncan's multiple range test.

$*, p<0.01 ; * *, p<0.001 ; * * *, p<0.02$. 
compounds in the extracts could be used to develop drugs in treatment of ailments caused by these microorganisms. Extracts also showed good activities against $S$. dysenteriae, the bacteria responsible for bacillary dysentery. The results reported in this study corroborate earlier literature data on antibacterial assessments of plant extracts (Ajala et al. 2020; Archana \& Abraham 2011; Ćetković et al. 2007; Chew, Jessica \& Sasidharan 2012; Kumar et al. 2010; Mahesh \& Satish 2008; Rafiu et al. 2019; Shihabudeen, Priscilla \& Thirumurugan 2010; Silva et al. 2016). The inhibitory activities of all extracts confirmed the potential use of the plant in the treatments of bacterial induced ailments.

\section{Conclusion}

The root of $P$. oleracea L. was collected to investigate its phytoconstituents and antibacterial potentials, with the goal of establishing the presence of bioactive constituents responsible for the medicinal applications of the plant. The study revealed antibacterial phytochemicals present in root extracts of $P$. oleracea L., which support its vast utilisation in ethno-medicine. Our study suggests that $P$. oleracea $\mathrm{L}$. could be a potential source for antibacterial drug discovery.

\section{Acknowledgements}

The authors are grateful to those who contributed immensely to the success of this study. They appreciate the effort of Mr. Odewo of the Forest Research Institute of Nigeria for plant authentication and assignment of voucher number.

\section{Competing interests}

The authors have declared that no competing interest exists.

\section{Authors' contributions}

E.O. Ojah designed the study and carried out all laboratory experiments. E.O. Ojah and E.O. Oladele wrote the first draft of manuscript. All authors read and approved the final manuscript.

\section{Funding information}

This research received no specific grant from any funding agency in the public, commercial or not-for-profit sectors.

\section{Data availability statement}

Data sharing is not applicable to this article as no new data were created or analysed in this study.

\section{Disclaimer}

The views and opinions expressed in this article are those of the authors and do not necessarily reflect the official policy or position of any affiliated agency of the authors.

\section{References}

Ajala, T.O., Olusola, A.J. \& Odeku, O.A., 2020, 'Antimicrobial activity of Ficus exasperato (Vahl) leaf extract in clinical isolates and its development into herbal tablet dosage form', Journal of Medicinal Plants for Economic Development 4(1), a95. https:// doi.org/10.4102/jomped.v4i1.95

Archana, S. \& Abraham, J., 2011, 'Comparative analysis of antimicrobial activity of leaf extracts from fresh green tea, commercial green tea and black tea on pathogens', Journal of Applied Pharmaceutical Science 1(8), 149-152.

Bajpai, M., Pande, A., Tewari, S.K. \& Prakash, D., 2005, 'Phenolic contents and antioxidant activity of some food and medicinal plants', International Journal of Food Sciences and Nutrition 56(4), 287-291. https://doi.org/10.1080/09637480500146606

Balandrin, M.F., Klocke, J.A., Wurtele, E.S. \& Bollinger, W.H., 1985, 'Natural plant chemicals: Sources of industrial and medicinal materials', Science 228(4704), 1154-1160. https://doi.org/10.1126/science.3890182

Balouiri, M., Sadiki, M. \& Ibnsouda, S.K., 2016, 'Methods for in vitro evaluating antimicrobial activity: A review', Journal of Pharmaceutical Analysis 6(2), 71-79. https://doi.org/10.1016/j.jpha.2015.11.005

Bhargav, H.S., Shastri, S.D., Poornav, S.P., Darshan, K.M. \& Nayak, M.M., 2016 'Measurement of the zone of inhibition of an antibiotic', in 2016 IEEE 6th International Conference on Advanced Computing (IACC), Bhimavaram, April 04-06, 2016, pp. 409-414.

Ćetković, G., Čanadanović-Brunet, J., Djilas, S., Tumbas, V., Markov, S. \& Cvetković, D. 2007, 'Antioxidant potential, lipid peroxidation inhibition and antimicrobial activities of Satureja montana L. subsp. kitaibelii extracts', International Journal of Molecular Sciences 8(10), 1013-1027.

Chan, K., Islam, M.W. \& Kamil, M., 2000, 'The analgesic and anti-inflammatory effects of Portulaca oleracea L. subsp. Sativa (Haw.) Celak', Journal of Ethnopharmacology 73(3), 445-451. https://doi.org/10.1016/s0378-8741(00)00318-4

Chen, C., Wang, W.Y. \& Wang, X.L., 2009, 'Anti-hypoxic activity of the ethanol extract from Portulaca oleracea L. in mice', Journal of Ethnopharmacology 124(2), 246-250. https://doi.org/10.1016/j.jep.2009.04.028

Chew, A.L., Jessica, J.J. \& Sasidharan, S., 2012, 'Antioxidant and antibacterial activity of different parts of Leucas aspera', Asian Pacific Journal of Tropical Biomedicine 2(3), 176-180. https://doi.org/10.1016/S2221-1691(12)60037-9

Chhetri, H.P., Yogol, N.S., Sherchan J., K.C.A., Mansoor, S. \& Thapa, P., 2008, 'Phytochemical and Antimicrobial evaluations of some medicinal plants of Nepal', Kathmandu University Journal of Science, Engineering and Technology 4(1), 49-54. https://doi. org/10.3126/kuset.v4i1.2883

Cowan, M.M., 1999, 'Plant products as antimicrobial agents', Clinical Microbiology Review 12(1), 564-582.

Dosumu, O.O., Ajetumobi, O.O., Omole, O.A. \& Onocha, P.A., 2019, 'Phytochemical composition and antioxidant and antimicrobial activities of Pergularia daemia', Journal of Medicinal Plants for Economic Development 3(1), a26. https://doi. org/10.4102/jomped.v3i1.26

Egwaikhide, P.A. \& Gimba, C.E., 2007, 'Analysis of the Phytochemical Content and Anti-microbial activity of Plectranthus glandulosis whole plant', Middel-East Journal of Scientific Research 2(3-4), 135-138.

Elkhayat, E.S., Ibrahim, S.R.M. \& Aziz, M.A., 2008, 'Portulene, a new diterpene from Portulaca oleracea L', Journal of Asian Natural Products Research 10(11-12), 1039-1043. https://doi.org/10.1080/10286020802320590

Essawi, T. \& Srour, M., 2000, 'Screening of some Palestinian plants for anti-bacterial activity', Journal of Ethnopharmacology 70(3), 343-349. https://doi.org/10.1016/ s0378-8741(99)00187-7

Ezekwe, M.O., Omara, A., Thomas, R. \& Membrahtu, T., 1999, 'Nutritive characterization of purslane accessions as influenced by planting date', Plant Food Hum Nutri(Dordrecht) 54(3), 183-191. https://doi.org/10.1023/A:1008101620382

Grierson, D.S. \& Afolayan, A.J., 1999, 'Antibacterial activity of some indigenous plants used for the treatment of wounds in the Eastern Cape, South Africa', Journal of Ethnopharmacology 66(1), 103-106. https://doi.org/10.1016/S03788741(98)00202-5

Harborne, J.B., 1998, Phytochemical method: A guide to modern methods of plant analysis, Chapman and Hall, London, pp. ix-271. https://doi.org/10.1007/978-94009-5921-7

Jain, S.K., 1994, 'Ethno botany and research on medicinal plants in India', Ciba Foundation Symposium 185(1), 153-164. https://doi.org/10.1002/9780470514634.ch11

Janet, F.H. \& John, S., 2007, 'Analysis and presentation of cumulative antibiograms: A new consensus guideline from the clinical and laboratory standards institute', Clinical Infectious Diseases 44(6), 867-873. https://doi.org/10.1086/511864

Jin, R., Lin, Z.J., Xue, C.M. \& Zhang, B., 2013, 'An improved association- mining research for exploring Chinese herbal property theory: Based on data of the Shennong's classic of Materia Medica', Journal of Integrative Medicine 11(5), 352-365. https://doi.org/10.3736/jintegrmed2013051

Karimi, G., Hosseinzadeh, H. \& Ettehad, N., 2004, 'Evaluation of the gastric antiulcerogenic effects of Portulaca oleracea L. extracts in mice', Phytotherapy Research 18(6), 484-487. https://doi.org/10.1002/ptr.1463

Kumar, G., Karthik, L. \& Bhaskara, R.K., 2010, 'Antimicrobial activity of latex from Calotropis gigantea against pathogenic microorganisms-an in vitro study', Pharmacology Online 3(3), 155-163.

Kumar, G.S., Jayaveera, K.N., Kumar, C.K.A., Sanjay, U.P., Swamy, B.M.V. \& Kumar D.V.K., 2007, 'Antimicrobial effects of Indian medicinal plants against acnehttps://doi.org/10.4314/tjpr.v6i2.14651 
Lee, A.S., Kim, J.S., Lee, Y.J., Kang, D.G. \& Lee, H.S., 2012, 'Anti-TNF- $\alpha$ activity of Portulaca oleracea in vascular endothelial cells' International Journal of Molecular Sciences 13(5), 5628-5644. https://doi.org/10.3390/ijms13055628

Li, J., Wu, X.L. \& Chen, Y., 2013, 'Antidiarrheal properties of different extracts of Chinese herbal medicine formula', Journal of Chinese Integrative Medicine 11(2), 125-134. https://doi.org/10.3736/jintegrmed2013019

Maatalah, M.B., Bouzidi, N.K., Bellahouel, S., Merah, B., Fortas, Z., Soulimani, R. et al., 2012, 'Antimicrobial activity of the alkaloids and saponin extracts of Anabasis articulate', Journal of Biotechnology and Pharmaceutical Research 3(3), 54-57.

Mahesh, B. \& Satish, S., 2008, 'Antimicrobial activity of some important medicinal plant against plant and human pathogens', World Journal of Agricultural Sciences 4(5), 839-843. https://doi.org/10.1080/22311866.2012.10719105

Malik, F., Hussain, S., Mirza, T., Hameed, A., Ahmad, S., Riaz, R. et al., 2011 'Screening for antimicrobial activity of thirty-three medicinal plants used in the traditional system of medicine in Pakistan', Journal of Medicinal Plant Research 5(14), 3052-3060,

Masoodi, M.H., Ahmad, B., Mir, S.R., Zargar, B.A. \& Tabasum, N., 2011, 'Portulaca oleracea L. A review', Journal of Pharmaceutical Research 4(1), 3044-3048.

Mbata, T.I., Debiao, L. \& Saikia, A., 2008, 'Antibacterial activity of the crude extract of Chinese green tea (Camellia sinensis) on Listeria minocytogenes', International Journal of Microbiology 7(1), 1571-1573.

Mbata, T.I., Debiao, L. \& Saikia, A., 2008, 'Antibacterial activity of the crude extract of Chinese green tea (Camellia sinensis) on Listeria minocytogenes', International Journal of Microbiology 7(1), 1571-1573.

Mir, M.A., Sawheny, S.S. \& Jassal, M.M.S., 2013, 'Qualitative and quantitative analysis of phytochemicals of Taraxacum officinale,' Wudpecker Journal of Pharmacy and Pharmocology 2(1), 001-005.

Motaleb, M.A., 2010, Approaches to conservation of medicinal plants and traditional Knowledge: A focus on the Chittagong Hill Tracts, IUCN, Dhaka.

Muthusamy, R., Karthiga, V., Lavanya, K., Deboral, P. \& Bernala, W., 2013 'Phytochemical screening and antibacterial activity of methanol extract of Tridax procumbens', International Journal of Pharmaceutical Bio Sciences 3(1), 521-524.

Narasimhan, R. \& Mohan, A., 2012, 'Phytochemical Screening of Sesamum Indicum seed Extract', World Journal of Pharmacy and Pharmaceutical Sciences 1(4), $1298-1308$.

Nasrullah, S.R.K., Ikram, M., Nisar, M. \& Khan, I., 2012, 'Screening of antibacterial activity of medicinal plants' International Journal of Pharmaceutical Sciences Review and Research 14(2), 25-29.

National Committee for Clinical Laboratory Standards (NCCLS), 1993, Dilution antimicrobial susceptibility for bacteria that group aerobically? Third edition: Approved standards, National Committee for Clinical Laboratory Standard Document M7-A3, Villanova, PA

Newman, D.J., Cragg, G.M. \& Snader, K.M., 2000, 'The influence of natural products upon drug discovery', National Product Reports 17(3), 215-234.

Njenga, P.K. \& Mugo, S.M., 2020, 'Chemical composition, antioxidant potential and antimicrobial activities of Ixora scheffleri subspecies keniensis essential oil', Journal of Medicinal Plants for Economic Development 4(1), a58. https://doi. org/10.4102/jomped.v4i1.58

Ojah, E.O. \& Kachi, J.B., 2020, 'Phytochemical investigation and antimicrobial activity of hexane, ethyl acetate and methanol fractions from stem Bark of Icacina Trichantha Oliv. (Icacinaceae)', Journal of Chemistry, Environmental Science and its Applications 7(1), 7-12. https://doi.org/10.15415/jce.2020.71002

Ojah, E.O., Moronkola, D.O. \& Osamudiamen, P.M., 2020, 'Antioxidant assessment of characterised essential oils from Calophyllum inophyllum Linn using 2,2-diphenyl1-picrylhydrazyl and hydrogen peroxide methods' Journal of Medicinal Plants for Economic Development 4(1), a83. https://doi.org/10.4102/jomped.v4i1.83

Palaniswamy, U.R., Bible, B.B. \& McAvoy, R.J., 2002, 'Effect of nitrate: Ammonium nitrogen ratio on oxalate levels of purslane', Trends in New Crops and New Uses 11(5), 453-455.
Palaniswamy, U.R., McAvoy, R.J. \& Bible, B.B., 2001, 'Stage of harvest and polyunsaturated essential fatty acid concentrations in purslane (Portulaca polyunsaturated essential fatty acid concentrations in purslane (Portulaca
oleraceae) leaves', Journal of Agricultural and Food Chemistry 49(7), 3490-3493. https://doi.org/10.1021/jf0102113

Parekh, J. \& Chanda, S.V., 2007, 'In vitro antimicrobial activity and phytochemical analysis of some Indian medicinal plants', Turkish Journal of Biology 31, 53-58.

Prasannabalaji, N., Muralitharan, G., Sivanandan, R.N., Kumaran, S. \& Pugazhvendan, S.R., 2012, 'Antibacterial activities of some Indian traditional plant extracts', Asian Pacific Journal of Tropical Disease 14(1), 291-295. https://doi.org/10.1016/ S2222-1808(12)60168-6

Rafiu, B.O., Sonibare, A.M. \& Adesanya, E.O., 2019, 'Phytochemical screening antimicrobial and antioxidant studies of Lannea egregia Engl. and K. Krause (Anacardiaceae) stem bark', Journal of Medicinal Plants for Economic Development 3(1), a62. https://doi.org/10.4102/jomped.v3i1.62

Ramanathan, R., Baby, R., Bhuvaneswarri, R. \& Dhandapani, R., 2013, 'Antimicrobial activities of Canthium parviflorum (lam.) and Pergularia daemia (Forsk) Chiov', International Journal of Comprehensive Pharmacy 4(9), 205-209.

Rashed, A.N., Afifi, F.U. \& Disi, A.M., 2003, 'Simple evaluation of the wound healing activity of a crude extract of Portulaca oleracea L. (growing in Jordan) in Mus musculus JVI-1', Journal of Ethnopharmacology 88(2-3), 131-136. https://doi. org/10.1016/S0378-8741(03)00194-6

Sawant, R.S. \& Godghate, A., 2013, 'Preliminary Phytochemical Analysis of leaves of Triday Procumbens Linn.,' International Journal of Science, Environment 2(3), 388-394.

Shihabudeen, M.H., Priscilla, D.H. \& Thirumurugan, K., 2010, 'Antimicrobial activity and phytochemical analysis of selected Ind. folk med plants', International Journal of Pharma Sciences and Research 1(10), 430-434.

Silva, R.A., Liberio, S.A., Amaral, F.M., Nascimento, F.R.N., Torres, L.M.B., Neto, V.M. et al., 2016, 'Antimicrobial and antioxidant activity of Anacardium occidentale L. flowers in comparison to bark and leaves extracts', Journal of Biosciences and Medicine 4(1), 87-99. https://doi.org/10.4236/jbm.2016.44012

Sofowora, A., 1993, 'Screening plants for bioactive agents', in Medicinal plants and traditional medicinal in Africa, 2nd edn.,pp. 134-156, Spectrum Books Ltd, Ibadan.

Talukda, A.D., Choudhury, M.D., Chakraborty, M. \& Dutta, B.K., 2010, 'Phytochemica screening and TLC profiling of plant extracts of Cyathea gigantea (Wall. Ex. Hook.) Haltt. And Cyathea brunoniana. Wall. ex. Hook.', Assam University Journal of Science and Technology 5, 70-74.

Tim-Cushnie, T.P. \& Andrew, J.L., 2005, 'Antimicrobial activities of flavonoids' Journal of Antimicrobial Agents 26(5), 343-356. https://doi.org/10.1016/ j.ijantimicag.2005.09.002

Tim-Cushnie, T.P., Benjamart, C. \& Andrew, J.L., 2014, 'Alkaloids: An overview of their antibacterial, antibiotic-enhancing and antivirulence activities', Journal of Antimicrobia Agents 44(5), 377-386. https://doi.org/10.1016/j.jijantimicag.2014.06.001

Trease, G.E. \& Evans, W.C., 2002, Pharmacognosy, vol. 15, pp. 333-337, WB Saunders Publishers, London.

Victor, N.O. \& Chidi, O., 2009. 'Phytochemical constituents of some selected medicinal plants', African Journal of Pure and Applied Chemistry 3(15), 228-223.

Walter, C., Shinwari, Z.K., Afzal, I. \& Malik, R.N., 2011, 'Antibacterial activity in herbal products used in Pakistan', Pakistan Journal of Botany 43(1), 155-162.

Wojdylo, A., Oszmianski, J. \& Czemerys, R., 2007, 'Antioxidant activity and phenolic compounds in 32 selected herbs', Food Chemistry 105(3), 940-949. https://doi. org/10.1016/j.foodchem.2007.04.038

Xu, X., Yu, L. \& Chen, G., 2006, 'Determination of flavonoids in Portulaca oleracea L. by capillary electrophoresis with electrochemical detection', Journal of Pharmaceutical and Biomedical Analysis 41(2), 493-499. https://doi.org/ 10.1016/j.jpba.2006.01.013

Zhao, C.Q., Zhou, Y., Ping, J. \& Xu, L.M., 2014, 'Traditional Chinese medicine for treatment of liver diseases: Progress, challenges and opportunities', Journal of Integrative Medicine 12(5), 401-408. https://doi.org/10.1016/S2095-4964(14)60039-X 